\title{
Third-Party Payment and Commercial Bank Competition Relationship After Nets Union Clearing Corporation Running
}

\author{
Yuguo Yang ${ }^{1}$ Shuyi Cai ${ }^{1, *}$ Hao Yang ${ }^{1}$
}

\author{
${ }^{1}$ School of Accounting, Guangzhou College of Commerce, Guangzhou, Guangdong 511363, China \\ *Corresponding author.Email: 853054897@qq.com
}

\begin{abstract}
Third-party payment has cooperated with banks since the first date of its birth and directly connected to commercial banks. The payment is completed online and it is fast and convenient. However, there is fierce competition in terms of capital attraction and payment. After Net Union Clearing Corporation (NUCC) is running, this kind of competition and cooperation relationship still exists, but the cooperation relationship has changed from direct to indirect, but the competition relationship is more intense than before. Based on the new type of relationship between third-party payment and commercial banks after the Nets Union Clearing Corporation running, this paper makes a new analysis and research on the competition and cooperation relationship between the two.
\end{abstract}

Keywords: nets union clearing corporation, third-party payment, commercial banks, co-operation relationship

\section{INTRODUCTION}

Since the Net Union Clearing Corporation Platform officially launched in 2018, commercial banks and third-party payments have changed from their original direct relationship to indirect relationships. However, the upstream and downstream relationships of the two industry chains still exist. While establishing a good cooperative relationship, competition in online payment, credit card and other overlapping businesses is also increasingly intense. As the two pillars of the currency payment market, the development of the relationship between third-party payment platforms and banks ingress with is very important to the construction and norm of the whole financial order. Although competition and cooperation have been coexisting for a long time, but due to the intervention of the network, the relationship between the two must be more competitive than cooperation. The purpose of this paper is to analyze the development process, status quo and characteristics of third-party payment platforms as well as the competition and cooperation between banks and the third-party payment. We will take Alipay as a specific case analysis, so as to explore the development direction of the future relationship between third-party payments and banking, and to make suggestions for the future development of the relationship between the two.

\section{THE DEVELOPMENT STATUS OF THIRD- PARTY PAYMENT IN CHINA AND THE MAIN PROFIT MODELS}

\section{A. Market size and brand development}

China's third-party payment has experienced three development stages, 1999-2004 for the initial stage; 2005-2013 for the rapid development stage, the government in this period is to encouraged and guided; 2014-present for the standard, guidance and monitoring stage. The specific scale of development in recent years can be seen in the following "Fig. 1": 


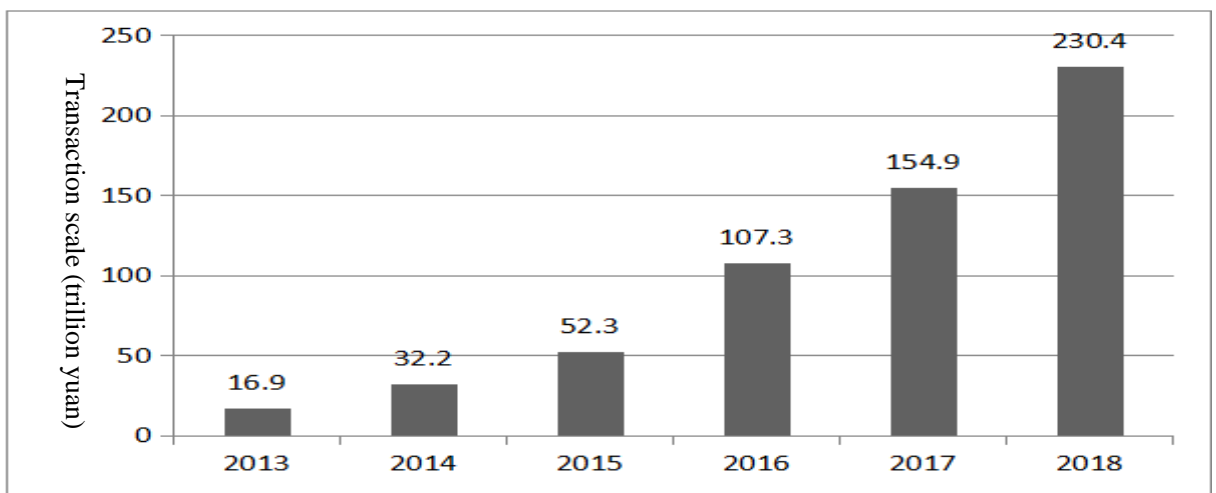

Fig. 1. China's third-party payment comprehensive payment transaction scale (trillion yuan), 2013-2018.

As can be seen from "Fig. 1", the volume of thirdparty payment transactions in 2018 reached 23.04 billion yuan, an increase of $48.74 \%$ over 15.49 billion a. Data source: iResearch yuan in 2017 , and 4.38 points higher than the previous year's $44.36 \%$, which is still in a high-speed development.

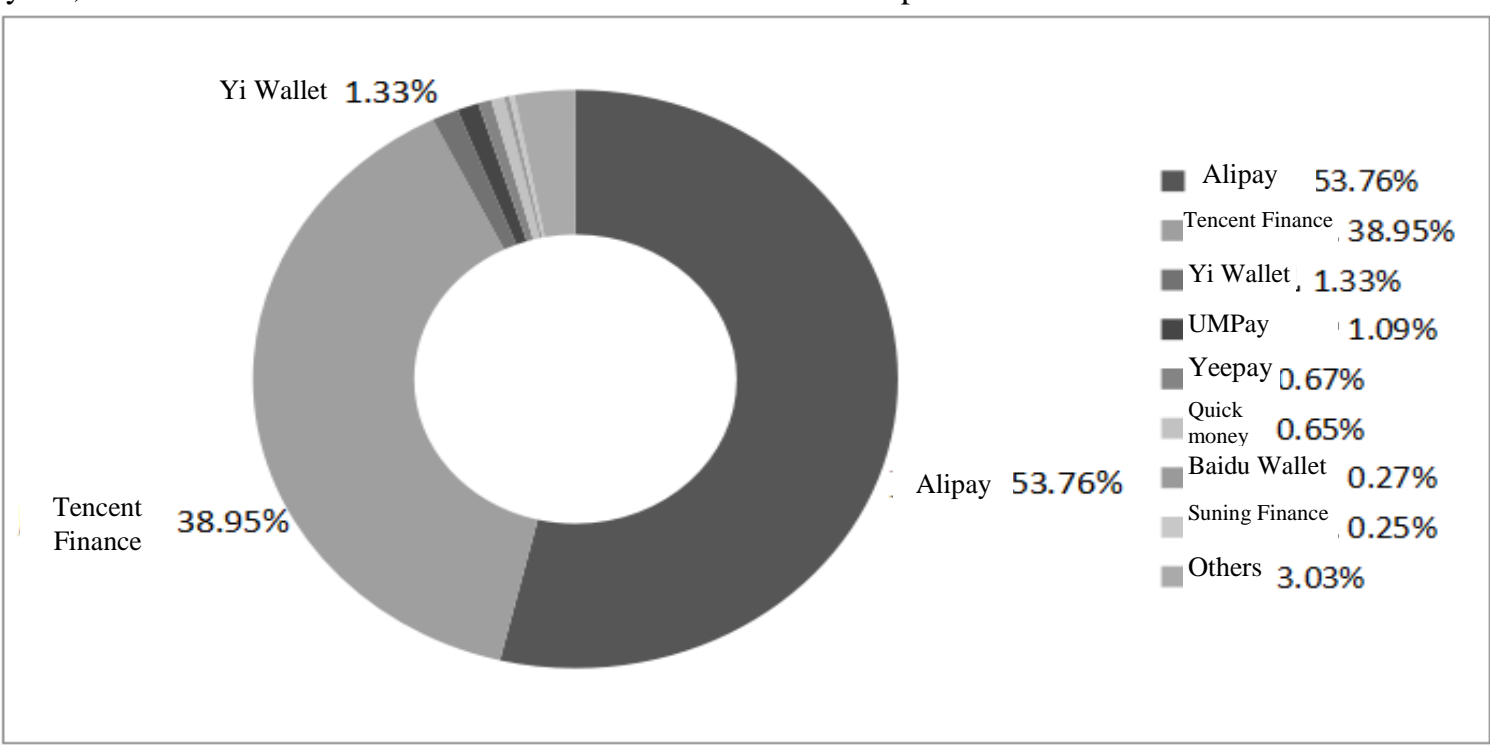

Fig. 2. Transaction share of China's third-party mobile payment market in the first quarter of 2018.

From "Fig. 2", we can see that the third-party payment of various brand development. In the first quarter of 2018, Alipay and Tencent Finance seized the market share of the third-party payment transaction market with an absolute advantage of $92.71 \%$. Among them, Alipay with 53.76 percent of the proportion of the firm, and then form Alipay and Tencent financial double oligarchs market pattern.

\section{B. The development trend of the third-party payment industry}

The development trend of third-party payment can be summarized into four aspects:

- the competition in the offline market is still fierce and expanding its business areas;
- gradually establishing and improving crossborder payment networks and expanding overseas markets;

- third-party payment use fintech methods which has made the collection tools more intelligent and increased the convenience and safety of transactions;

- Industry policy control is more stringent, the industry standardization of development has become an inevitable trend. Consumer payments are being paid for life services, credit card spending repayment, travel, education payment, financial insurance, digital entertainment, medical logistics and other fields of 
TABLE I. DEVELOPMENT TRENDS OF THIRD-PARTY PAYMENTS DATA SOURCE: FORESIGHT INDUSTRY

\begin{tabular}{|c|l|}
\hline mode & $\begin{array}{l}\text { From payment service provider to an operation service provider, to provide financial services with the concept of } \\
\text { precision marketing }\end{array}$ \\
\hline Scenes & $\begin{array}{l}\text { Gradually penetrate third-tier and fourth-tier cities and rural markets, full coverage of offline life services scene, } \\
\text { while opening up overseas cloth market, to provide cross-border payment services technology }\end{array}$ \\
\hline technology & $\begin{array}{l}\text { The third-party integrate a variety of payment tools, including bank cards, IC cards, QR codes, prepaid cards, fusion } \\
\text { biometrics, Internet of Things technology, regional chain technology applications, terminal intelligence, and } \\
\text { enhanced big data analytics. Biosciences such as fingerprinting, sound waves, irises and facial recognition have been } \\
\text { widely used in the field of third-party payment. }\end{array}$ \\
\hline service & $\begin{array}{l}\text { Services provide accounting management, operation management, merchant flow loans, consumption installments, } \\
\text { offline B-side operation management, member marketing management, invoice issuance and other value-added } \\
\text { services }\end{array}$ \\
\hline policy & $\begin{array}{l}\text { The state has gradually increased the supervision of third-party payment, as far as possible to avoid third-party } \\
\text { payment platforms become a greenhouse of crime }\end{array}$ \\
\hline
\end{tabular}

In October 2018, since the operation of the Net Union Clearing Corporation, the financial supervision policy has gradually become stricter. The growth rate of the third-party payment industry has slowed sharply, resulting in payment institutions returning to the essence of the payment business, more development of non-interest business but the payment giants use itself advantages to get opportunities for centralized development and international development.

\section{Third-party payment profit model}

Taking Alipay as an example, its profit model mainly has seven major areas:

- Financial value-added services, and the balance sheet created by Alipay and Tianhong Fund for individual users is a value-added service;

- Fees for various services, including technical service fees for taobao sellers, alipay collection and payment fees;

- The company charges in the b2c transaction, and what we call b2c service is now pays the bills of water and electricity media, transportation fines, and communication fees, etc. There are also many large online retailers such as JD.com and Amazon Primr have also used the Alipay platform. These companies are required to pay a certain fee to Alipay;

- Advertising revenue, ads posted on the Alipay homepage are targeted Strong, including banner ads, button ads, interstitial ads, etc;

- Relying on online merchant banks for bank deposit and loan business, Alipay cooperates with online merchant banks. Similar deposits by the bank into the virtual Alipay, reinvest and borrow to obtain the income;

- Collecting service fees. Alipay's virtual balance withdrawal reaches a certain amount of revenue service fees. Of course, this is not its original intention, but after the network connection runs, will be carried out more frankly;

- Big data services, Alibaba Data and Alibaba Cloud are not free to use, at least not for a long time. Its acquisition of Gaode, Hammer, uc, etc. are all collecting your personal data, understanding your personal habits, family Address, work situation, etc, and then accurate analysis of you, classification, give you ant credit pay, ant pay, loans, etc. So it is a data bank that generates a large amount of valueadded business from data.

\section{COMPARISON OF ADVANTAGES AND DISADVANTAGES OF THIRD-PARTY PAYMENTS AND COMMERCIAL BANKS AND ANALYSIS OF COMPETITION AND COOPERATION RELATIONSHIPS}

\section{A. Advantages and disadvantages of third-party payments compared with commercial banks}

1) Information resources advantage: In the era of big data, the role of Internet information is very complex, some information from different commercial banks can be shared, and they do not disclose the data of many companies and individual customers. Banks can independently review customers' credit, wealth and the liquidity of capital, with significant advantages in terms of information resources. Therefore, commercial banks can conduct more concentrated and efficient analysis of business information of the entire industry, which has a competitive advantage over third-party payment. Third-party payment platform virtually impossible to understand the customer's credit, assets and cash flow based on the customer's payment alone. This situation show us the third-party payment platform has no advantage over the bank in the resources and information of the customer. 
2) Security advantages: Security is one of the three major characteristics of business activities of commercial banks. There is no doubt that the security is the first factor for the public to choose products. At present, China's commercial banks use the security technology is also in the forefront of the world. They can basically meet the security requirements of online transactions and combat fake identity and online fraudulent methods.

3) Providing final payment function: As the initial payer and ultimate beneficiary of a payment transaction, commercial banks are connected to the payment chain throughout the transaction, so it can provide a wider range of guarantees in the flow of funds, while supporting the implementation of the payment function of the third-party payment platform.

4) The relationship with $C 2 C$ is not close: The $\mathrm{C} 2 \mathrm{C}$ market is characterized by low payments, amount diffusion, greater risk, and further personalization of customer needs. Commercial banks lack competitive advantage in the c2c market because of their lack of targeted services provided to customers.
5) Customer loyalty to fixed banks is not high: In Nielsen's research on bank customer loyalty, customers had no particular preference for commercial banks and their financial products and services, with only $10 \%$ of Chinese respondents indicated that they would be loyal to one bank. This may be related to the bank's not being customer-oriented.

\section{B. Competitive relationship between third-party payments and commercial banks}

1) Intermediate business dispute: The deposit and loan spread of commercial banks begins to shrink with the constant adjustment of the deposit and loan interest rate of the central bank of our country. The main profits come from the intermediary business, covering settlement, agency, guarantee, financing, information consulting, and derivative financial instrument transactions. In recent year, payment platforms have provided services in low cost or even free, such as remittances, offline receipts, medical insurance payments and other convenience services. These competitive measures have seriously affected the business share of commercial banks.

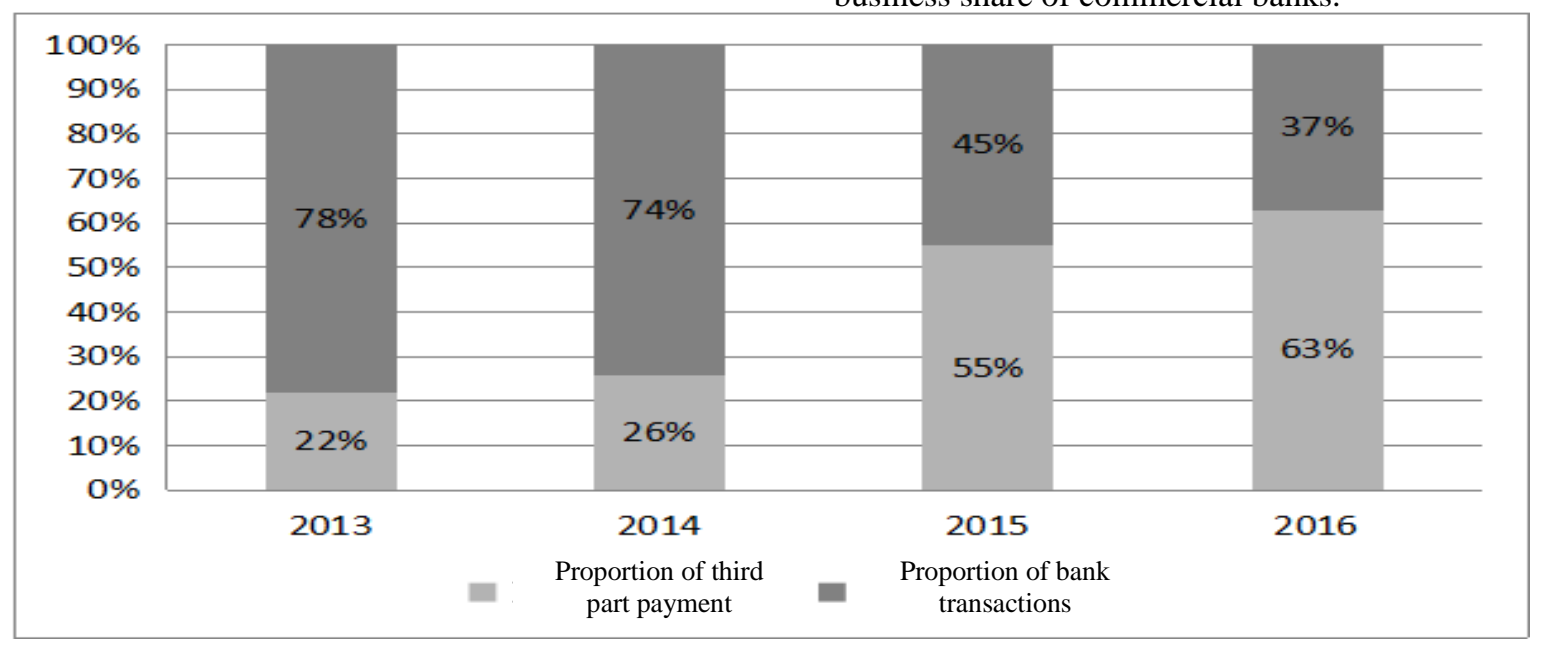

Fig. 3. Proportion of transaction amount of bank card acquiring business

From "Fig. 3", we can see that in recent years in the intermediary business in the bank card line collection market, the third-party payment institution's transaction proportion gradually increased, while the proportion of bank transactions has decreased. Third-party payment platforms are covering the entire payment market in a rapid state.

2) User contention: Taking Alipay as an example, Alipay launched in April 2013 can quickly deposit to various bank cards through Alipay within 50,000 yuan per day and waived the handling fee. In June of the same year, the introduction of Yu'E Bao could enable users to earn interest income without affects its payment function at any time. Until December 2017, the number of users for who is using the Yu'e Bao service has exceeded 400 million. In September 2017, China UnionPay launched a UnionPay QR code subsidy with major banks, while for the collection agencies and service providers to launch incentive mechanism, each development of a new customer has a 20 yuan incentive, each consumption has 0.5 yuan -2 yuan incentive fee, improve the bank APP user activity and stickiness, the two users of the ruling more and more intense. 
TABLE II. FINANCIAL APP RANKINGS IN SEPTEMBER 2017

\begin{tabular}{|l|l|l|l|l|}
\hline Ranking & \multicolumn{1}{|c|}{ app name } & \multicolumn{1}{|c|}{ Realm name } & $\begin{array}{c}\text { Monthly active user } \\
\text { scale(10,000 people) }\end{array}$ & \multicolumn{1}{|c|}{$\begin{array}{c}\text { Active users (increase from the } \\
\text { previous quarter\%) }\end{array}$} \\
\hline 1 & Alipay & Pay & $38,235.07$ & $-0.76 \%$ \\
\hline 2 & China Construction Bank & Banking Service Application & $4,109.22$ & $4.03 \%$ \\
\hline 3 & ICBC & Banking Service Application & $4,079.10$ & $3.88 \%$ \\
\hline 4 & Flush stocks & Securities service applications & $3,610.70$ & $-3.06 \%$ \\
\hline 5 & China Merchants Bank & Banking Service Application & $2,401.73$ & $1.93 \%$ \\
\hline 6 & ICBC Financial e-Link & Banking Service Application & $2,343.72$ & $-4.45 \%$ \\
\hline 7 & Agricultural Bank of China & Banking Service Application & $2,186.14$ & $5.94 \%$ \\
\hline 8 & Palm life & Banking Service Application & $2,085.31$ & $2.88 \%$ \\
\hline
\end{tabular}

From "Table II" above, we can see that although Alipay is still ranked first, but its growth has been negative, while the bank's generally active users' growth is more than Alipay, the bank's user prospects are good.

\section{COOPERATION RELATIONSHIP BETWEEN THIRD-PARTY PAYMENT AND COMMERCIAL BANKS}

The third-party payment platforms have established cooperative and complementary relationships with commercial banks in the field of online credit, fast payment and fund custody, and perfected the entire payment transaction system.

\section{A. The operation of third-party payment platforms is inseparable from the support of commercial banks}

Before the operation of the Net Union Clearing Corporation, the cooperation between the two parties showed mutual access during the transfer and settlement of funds. After all, third-party payment does not open an account directly, and the salaries of the general public are also sent to bank cards instead of third-party payment accounts. Later, although the relationship between the two parties was not direct, it still had an indirect relationship through the network connection platform.

\section{B. Third-party payment platforms can promote the development of commercial banks}

Due to the convenience and widespread popularity of third-party payment business, especially with all kinds of living payment platform docking, such as paying traffic fines, paying utility bills, buying airline tickets and so on, greatly convenient for users, which forced commercial banks to maintain offline scene business advantages at the same time, have set up online Internet business. Various types of apps and living services of commercial banks have also been developed and improved. Therefore, to a certain extent, third-party payments have promoted the improvement of commercial bank services and development.

\section{Proposals For THE DEVELOPMENT OF THE RELATIONSHIP BETWEEN THIRD-PARTY PAYMENTS AND COMMERCIAL BANKS}

\section{A. Strengthening technical security cooperation}

Although the People's Bank of China has always advocated the sharing of information from various financial institutions, especially in the evaluation of user credit information, as a public resource for sharing, but so far, progress has been slow. Alipay and other third-party payment platform, has a large number of user transaction information, third-party payment platform can be similar to "credit evaluation intermediary". The transaction records and credit evaluations provided by commercial banks through third-party payments such as Alipay as the result of external credit ratings can reduce the cost of obtaining and processing credit information by commercial banks, and improve the efficiency of commercial bank loan review. To prevent excessive bank debt ratios and increase the proportion of non-performing loans, Alipay and commercial banks' cooperation on credit information provides a strong basis for personal and SME financing.

\section{B. Cooperation in the field of anti-money laundering}

The virtual unboundedness of the Internet, the blurring of identities and the rapid concealment of operations have made online payments a breeding ground for money laundering. Criminals have exploited loopholes in the financial system to allow illegal funds to circulate and disperse in multiple accounts, so that they avoid the state's funds monitoring, become legally available funds. The "Administrative Measures on Payment and Clearance" formulated by the Chinese government in the early days can no longer meet the needs of the era of Internet finance, and the state has made it clear that third-party payment platforms has the obligation to perform anti-money laundering. The thirdparty payment platforms can cooperate with banks in the field of anti-money laundering, conduct identity information exchange and identification, jointly 
monitor payment transactions, jointly conduct investigations, and crack down on money laundering criminal activities.

\section{Fair competition customers}

In the era of big data, third-party payment platforms and banks will inevitably compete with customers, which is not good for both parties, so third-party payment platforms and banks should implement differentiated development based on their own advantages and disadvantages. The advantage of the bank through its own long-term formation of professional skills, knowledge and fixed process to provide customers with professional, stable, large financial services, but the third-party payment platform in the fee rate, small payment settlement, payment model of personalized customization and other advantages are far greater than the bank. The thirdparty payment institutions do not have the qualifications to close and sell foreign exchange, but banks can carry out valet collection and payment and valet settlement of foreign exchange business. Therefore, both sides should continue to play their own advantages, in the advantage area to obtain brand benefits.

\section{Benign competition for the payment market}

Third-party payment platforms and banks will inevitably generate fierce competition in the payment market because of the coverage of the business field, and even give up their business modules to snatch each other's business, which will pay unnecessary costs and form a vicious circle. The third-party payment platform because of its own Internet characteristics to make its development and service more personalized needs, with diverse business models and rapid innovation and upgrades. Commercial banks have satisfied the b2c and $\mathrm{b} 2 \mathrm{~b}$ fields with timely settlement, with advantages such as low capital transfer costs, fast speed, and security and stability which is the third party cannot compared now. Therefore, commercial banks should continue to use their inherent technological cost advantages in the traditional financial service field to meet the b2c and b2b market needs and then try to develop the $c 2 c$ market. And third-party payment platforms can continue to innovate and develop functions that are more suitable for the management of SME funds in the c2c field and the personalized development of financial management industry services, improve their own credit coefficient, and establish their own brand image.

\section{E. Competition and cooperation drive innovation}

Based on the inevitable competition and cooperation relationship between the two parties, the third-party payment platforms and commercial banks should focus on the macroeconomic strategies such as increasing financial consumer demand and RMB internationalization, and use innovation as the driving force to increase the development of mutual payment products and services. Continuously improve each other's service capabilities and levels for common development. At the same time cooperate with each other to provide customers with multi-channel, highly convenient and modern payment methods to achieve the orderly and healthy development of the financial industry and improve modern financial functions.

\section{CONCLUSION}

At present, third-party payment platform has both competition and cooperation with commercial banks. On the one hand, cooperation is due to a certain degree of protection of commercial banks by the state. On the other hand, if the market economy is fully competitive for the long-term, third-party payment platform will have greater development potential than commercial banks. The reason is that commercial banks represent traditional service business, while third-party payment platform represents more scientific and technological in financial innovation. Therefore, the development direction of advanced productivity of third-party payment platform is promising.

\section{References}

[1] Sun Lihui, Xu Shifeng, Li Chunqing. Cooperative competition game model and its application [j]. Journal of Systems Engineering 2002, 7 (3): 211-215.

[2] Yang Yuguo, Yuan Zepei. Spillover effect of online settlement on third party payment [j]. Finance and Accounting Monthly. 2018, 06 (03), 112-116

[3] Yang Yuguo. "Benefits" or "Bads"? The Impact of Netlink Liquidation on Third Party Payments: Observation of Alipay's Shareholding in Netlink as a Slice [j]. Times Finance, 2019 (12), 380-389

[4] Guan Muqin. Research on the Relationship between Third-party Payments and Commercial Banks' Competition and Cooperation - Taking Alipay as an Example [j]. Financial Economy 2018, (22), 63-64.

[5] Guo, F., Kong, S.T., Wang, J. General Patterns and Regional Disparity of Internet Finance Development in China: Evidence from the Peking University Internet Finance Development Index [J]. China Economic Journal, 2016, 9 (3): 253-271.

[6] Anguelov, C.E., Hilgert, M.A., Hogarth, J.M. U.S. Consumers and Electronic Banking, 1995-2003 [R]. Federal Reserve Bulletin, Winter 2004. 